JOANNA JÓŹWICKA, MONIKA KULWICKA,

Instytut Politologii UMK

\title{
Geneza i rozwój Europejskiego Obszaru Szkolnictwa Wyższego
}

B udowa zintegrowanej Europy jest procesem trwającym od ponad pięćD dziesięciu lat. W 1946 roku Winston Churchill zaapelował o utworzenie „Stanów Zjednoczonych Europy”. Od tego czasu na kontynencie europejskim wiele się zmieniło. Począwszy od utworzenia Europejskiej Wspólnoty Węgla i Stali, poprzez Europejską Wspólnotę Gospodarczą i EURATOM, aż po podpisanie w 1992 roku Traktatu z Maastricht, ustanawiającego Unię Europejską i przypięczętowującego unię gospodarczej i polityczną. Integracja europejska to jednak nie tylko wspólny rynek, ale także współpraca na wielu innych polach. Za jeden $\mathrm{z}$ ambitniejszych projektów można uznać próbę stworzenia Europejskiego Obszaru Szkolnictwa Wyższego (Espace Européen de l'Enseignement Supérieur). W 1998 roku, podczas gdy minister spraw zagranicznych Francji Dominique Strauss-Khan promował ideę wspólnej waluty, minister edukacji tego kraju - Claude Allègre, we współpracy ze swoimi odpowiednikami z Wielkiej Brytanii, Włoch i Niemiec, podjął próbę powołania do życia „Europy Edukacji”(„Europe de l'éducation”). Tak narodził się Proces Boloński - jak dotąd - najbardziej efektywny motor przemian na gruncie szkolnictwa wyższego w Europie. Twórcy projektu za jego cel uznali harmonizację do 2010 roku zróżnicowanych pod wieloma względami europejskich systemów edukacji. Ideę poparły inne państwa Unii i szybko okazało się, że skala i zasięg inicjatywy przekracza jej pierwotne założenia, nie ograniczając się jedynie do państw tworzących Unię Europejską. Do dnia dzisiejszego dużo już na ten temat powiedziano, ale nadal pozostaje wiele do zrobienia. 
W pierwszej części pracy zostanie przedstawiona geneza i kolejne etapy procesu harmonizacji szkolnictwa wyższego w Europie. Druga część będzie stanowić próbę podsumowania funkcjonowania Procesu Bolońskiego, ze szczególnym uwzględnieniem kwestii związanych ze studentami, jako uczestnikami tego przedsięwzięcia.

\section{Pierwsze kroki ku Europie Edukacji}

Przepływ osób to jedna z czterech podstawowych swobód wspólnego rynku Unii Europejskiej. Choć Traktat Rzymski z 1957 roku przewidywał jedynie swobodny przepływ towarów związanych z sektorem przemysłu węglowego i stalowego, to niektóre jego założenia wiązały się z przyszłym projektem nieskrępowanego przepływu osób w ramach Wspólnoty. Mimo braku regulacji prawnych, studenci z krajów europejskich już od lat 50. starali się poszerzać wiedzę i zdobywać doświadczenie, odbywając część studiów poza granicami własnych krajów (idea mobilności jest zresztą obecna w Europie już od czasów renesansu). Napotykali jednak na swojej drodze wiele trudności, z których największą okazywała się być kwestia nostryfikacji dyplomów i harmonizacji programów nauczania. Co ciekawe, problemy te jako pierwsza zauważyła Rada Europy - instytucja powołana w 1949 roku dla promocji idei współpracy oraz postępu społecznego i ekonomicznego. Realizując swe cele, podjęła ona działania na rzecz umożliwienia studentom i pracownikom naukowym wymiany międzynarodowej, pozwalającej na obieg doświadczeń, nowych metod nauczania i projektów badawczych na szczeblu europejskim. Mobilność społeczności akademickiej przyczyniła się natomiast do budowania tożsamości europejskiej.

Zasadniczą kwestią wymagającą regulacji była uznawalność dyplomów oraz, w przypadku, gdy student chciał kontynuować lub odbyć część studiów zagranicą, uznanie jego dotychczasowego dorobku z uczelni macierzystej przez zagraniczną. W takiej sytuacji student występował do uczelni przyjmującej z wnioskiem o uznanie jego wcześniejszych osiągnięć. Nie miała ona jednak i nie ma po dzień dzisiejszy obowiązku uwzględniania takiej prośby i decyzja w tej sprawie pozostaje w jej gestii. Także Traktat z Maastricht nie rozwiązał problemu stanowiąc jedynie, że państwa członkowskie mogą $\mathrm{w}$ omawianej materii postępować według samodzielnie wypracowanych zasad.

Mimo wszystko, aby promować wymianę między uczelniami, począwszy od 1953 roku, podpisano w ramach Rady Europy szereg konwencji uni- 
wersyteckich (Serie des Traités Européens) ${ }^{1}$. Pierwszy krok na drodze do porozumienia $\mathrm{w}$ ramach różnych systemów edukacyjnych państw europejskich stanowił STE nr 15 sygnowany w 1953 roku (a w 1964 uzupełniony o STE nr 49), czyli konwencja dotycząca uznawalności dyplomów, umożliwiająca studentom wstęp na zagraniczne uczelnie wyższe. W 1956 roku podpisano STE nr 21 odnoszący się do uznawalności odbytego okresu studiów. Na jego podstawie okres studiów odbyty przez studenta na uniwersytecie kraju członkowskiego Rady Europy, zaczął być traktowany w jego kraju jako równoważny. Należy jednak dodać, że konwencja ta dotyczyła w zasadzie tylko studiów lingwistycznych, w ramach których najczęściej przebiegała wymiana.

W 1997 roku w Lizbonie podpisano STE nr 165 - wspólną konwencję UNESCO i Rady Europy, stanowiącą podsumowanie wszystkich poprzednich ustaleń i skupiającą się na kwestiach „uznawalności” w ogóle (dyplomów, okresu przebytych studiów). W dokumencie tym zawarto ideę dołączania do dyplomu suplementu (le supplément au diplôme), stanowiącego wykaz wszystkich zaliczeń i osiągnięć, uzyskanych przez studenta przez cały okres studiów. Mimo wymienionych porozumień, studenci nadal zmagali się z wieloma trudnościami - głównie natury proceduralnej.

Właśnie dlatego, aby zachęcić ich do większej mobilności, Wspólnota Europejska, począwszy od lat 70., inicjuje różnorodne programy edukacyjne, które mają na celu rozwój współpracy między uniwersytetami europejskimi. Najbardziej znanym jest zapoczątkowany w 1987 roku program ERASMUS (EuRopean Action Scheme for Mobility University Student), który nadał nowy kierunek współpracy międzyuniwersyteckiej. Umożliwia on studentom uzyskanie stypendium, pozwalającego im choć w części pokryć koszty studiów za granicą. Ponadto, ponieważ kwestia wzajemnej uznawalności odbytych studiów stała się na mocy wcześniej podpisanych konwencji nieodłącznym warunkiem mobilności studentów, wprowadzono tzw. system ECTS (European Credit Transfert System). Dzięki niemu uczelnia macierzysta ma możliwość porównania i uznania osiągniętych przez swojego studenta wyników na uczelni partnerskiej. System transferu kredytów pozwolił na uzgodnienie uznawanej powszechnie metody oceniania, ta z kolei stała się podstawą harmonizacji programów nauczania. Oznacza to, że student przebywający na rocznym stypendium zagranicznym, po powrocie na uczelnię macierzystą powinien

Série des Traites européennes to zbiór rozmaitych konwencji, porozumień, układów, kodeksów, czyli instrumentów prawnych, będących traktatami w myśl Konwencji wiedeńskiej o prawie traktatów. Są one podpisywane w ramach Rady Europy, i dotyczą kwestii, którymi zajmuje się ta organizacja i jedynie $\mathrm{z}$ dwoma wyjątkami są to traktaty wielostronne. Wszystkie są dostępne na oficjalnej stronie internetowej rady Europy: http://conventions.coe.int/Treaty/Commun/ListeTraites.asp?CM=8\&CL=FRE [12.10.2007]. 
mieć możliwość kontynuowania studiów na kolejnym roku. Cechą szczególną kredytów ECTS jest ich „wartość europejska”, a więc fakt, że kredyty raz zebrane, będą uznawane i ważne na wszystkich uniwersytetach uczestniczących w procesie. Tym samym studenci uzyskali możliwość opracowania własnego programu studiów i to od nich ma zależeć czy będą mobilni, czy nie. Mimo to, należy zauważyć, że liczba studentów korzystających z programu ERASMUS w latach 1987-2001 (850 tys.) stanowiła jedynie ułamek ogólnej liczby studentów w Europie (72,5 mln w 2003 roku).

\section{Modernizacja szkolnictwa wyższego w ramach Europejskiego Obszaru Szkolnictwa Wyższego}

Mimo tych działań, do wczesnych lat 90. XX wieku strategie i tendencje strukturalne w wyższym szkolnictwie były w sposób oczywisty zgodne ze strategią i rozwojem państw ${ }^{2}$. Dopiero kroki podjęte pod koniec dekady, stały się realnym punktem wyjścia dla działań o charakterze ponadnarodowym.

Projekt pełnej harmonizacji europejskiego szkolnictwa wyższego został zainicjowany przez ministra edukacji Francji - Claude'a Allègre'a (pełniącego tę funkcję w latach 1997-2000). Jego pierwotnym celem była modernizacja szkolnictwa wyższego we Francji, przeprowadzona poprzez modyfikację kształcenia uniwersyteckiego. Minister chciał upodobnić je do systemu tzw. grandes écoles, czyli sieci placówek, powołanych do kształcenia wyższych urzędników państwowych i kadr kierowniczych (francuskich elit politycznych), po to, aby „przygotować Francję do konkursu w trudnej dziedzinie, jaką jest XXI wiek"3.

W 1997 roku Allègre powołał na urząd koordynatora reformy Jacques'a Atalli. Następnie powstała „Komisja Atalli”, licząca czternastu specjalistów z dziedziny edukacji: badaczy naukowych, nauczycieli akademickich, rektorów. Pomimo że raport sporządzony przez Komisję miał jedynie wymiar narodowy, wkrótce został rozszerzony na systemy szkolnictwa wyższego $\mathrm{w}$ innych krajach europejskich. Promował on przede wszystkim przyjęcie ujednoliconego cyklu kształcenia w ramach trzech stopni: licencjatu, magisterium i doktoratu (la License, le Master et le Doctorat: le LMD).

W maju 1998 roku ministrowie edukacji Francji, Włoch, Niemiec i Wielkiej Brytanii spotkali się w Paryżu, z okazji 800-lecia Sorbony, aby raz jeszcze omówić kwestię nowego systemu szkolnictwa wyższego. Spotkanie

S. Guri-Rosenblit, Proces boloński w Europie: pomiędzy przeciwstawnymi trendami, „Forum oświatowe", nr 2, 2007, s. 9.

Préparer la France à cette compétition de la matière grise que sera le XXI siècle. 
zakończyło się podpisaniem Deklaracji Sorbońskiej, będącej apelem o stworzenie Europejskiego Obszaru Szkolnictwa Wyższego (EOSW).

Deklaracja Sorbońska stanowi kontynuację Konwencji Lizbońskiej z 1997 roku, zakładającej rozwój systemów szkolnictwa wyższego państw europejskich, w kierunku ułatwienia wzajemnego uznawania przez nie dyplomów. Innym, nie mniej ważnym celem dyskutujących w Paryżu, było uatrakcyjnienie europejskiej oferty edukacyjnej i uczynienie jej konkurencyjną w stosunku do amerykańskiej, która przyciąga $28 \%$ ogółu studentów zagranicznych. Aby zrealizować to ambitne zamierzenie ministrowie ustalili główne wytyczne reformy. Są to: harmonizacja struktury studiów i stworzenie wspólnego cyklu nauczania opartego na wspomnianych trzech stopniach, odpowiadających trzem, pięciu i ośmiu latom studiów (LMD) oraz promocja mobilności studentów w ramach wspólnoty, poprzez wprowadzenie nowego systemu uzyskiwania zaliczeń, opartego na schemacie ECTS.

Do programu zaproszono także inne państwa europejskie. Chęć współpracy $\mathrm{w}$ tej dziedzinie zadeklarowało dwanaście krajów: Niemcy, Belgia, Bułgaria, Dania, Francja, Włochy, Czechy, Rumunia, Wielka Brytania i Szwajcaria.

Konferencja Sorbońska stała się impulsem do zorganizowania w czerwcu 1999 roku szczytu ministrów edukacji krajów europejskich w Bolonii. Należy podkreślić, że Konferencja Bolońska skonkretyzowała idee Deklaracji Sorbońskiej doprowadzając do powołania projektu europejskiego, znanego jako „Proces Boloński”. Zawiera on sześć płaszczyzn, zmierzających do sfinalizowania EOSW: harmonizację dyplomów, przyjęcie dwóch podstawowych cykli kształcenia (licencjat i magisterium) oraz cyklu badań naukowych (doktorat), stworzenie systemu kredytów uznających dorobek studenta, zniesienie barier utrudniających wymianę studentów (administracyjnych, finansowych czy akademickich). Podczas spotkania w Bolonii zadeklarowano również konieczność promocji współpracy europejskiej w dziedzinie podnoszenia jakości kształcenia. Wyrażono też zamiar wypracowania wspólnych kryteriów funkcjonowania i metodologii oraz potrzebę rozpowszechniania idei europejskich w szkolnictwie wyższym (zwłaszcza w zakresie zintegrowanych programów studiów, współpracy między placówkami badawczymi, promocji koncepcji umożliwiających mobilność środowiska naukowego).

Cele te mają zostać osiągnięte do 2010 roku. Należy podkreślić, że Proces Boloński opiera sie na dobrowolnych deklaracjach państw sygnatariuszy i nie ma postaci konwencji europejskiej. Będąc jedynie porozumieniem pomiędzy państwami europejskimi, nie nakłada na państwa obowiązku implementacji ustalonych zasad i nie przewiduje sankcji w przypadku braku ich realizacji w ustalonym terminie. Warto dodać, że „Plan działań na rzecz mo- 
bilności" (Plan d'action pour la mobilité) wprowadzono pod kierunkiem Francji i za zgodą Komisji Europejskiej. Zostanie on wdrożony przez ministrówsygnatariuszy, którzy tym samym potwierdzą swoją wolę zniesienia barier w mobilności uniwersyteckiej w Europie. Temu celowi ma służyć między innymi zwiększenie finansowania programów mobilnościowych.

W maju 2001 roku w Pradze miało miejsce spotkanie ministrów krajów uczestniczących w Procesie Bolońskim, które zakończyło się podpisaniem tzw. Komunikatu Praskiego, potwierdzającego cele i założenia Deklaracji Bolońskiej. Komunikat opierał się na rekomendacjach grup pilotażowych, powstałych w Bolonii oraz zaleceniach rektorów uniwersytetów uczestniczących w procesie, które wcześniej ustalono w Salamance.

Bilansu ustaleń przyjętych na spotkaniu w Pradze dokonała kolejna Konferencja ministrów edukacji, która odbyła się w Berlinie we wrześniu 2003 roku. Szczególną uwagę zwrócono w jej trakcie na konieczność polepszenia jakości kształcenia przez jednostki uniwersyteckie. Ponadto postanowiono, że każde państwo przedstawi do 2005 roku szczegółowy raport dotyczący realizacji założeń Procesu Bolońskiego. Potwierdzono ponownie, że priorytety to: wprowadzanie systemu opartego na dwóch cyklach (licencjat, magisterium) oraz uznawanie dyplomów i okresów studiów odbywanych przez studentów poza uniwersytetami macierzystymi. Powołano także stałą grupę, której celem jest ocenianie postępu w realizacji założeń reformy wprowadzonej przez Proces Boloński.

Kolejna konferencja odbyła się w Bergen (Norwegia), w maju 2005 roku. Komunikat podpisany przez szefów delegacji na niej obecnych (zatytułowany „Osiąganie Celów w Europejskim Obszarze Szkolnictwa Wyższego”) odwołuje się do szeregu zamierzeń, które już wcześniej zostały sformułowane. Rysuje też nowe obszary aktywności akademickiej, które należałoby uwzględnić w funkcjonowaniu szkół wyższych w nadchodzących latach. Konferencje ministrów stały się ważnym forum wymiany poglądów i refleksji nad wdrażaniem i udoskonalaniem Procesu Bolońskiego. Ostatnie ze spotkań odbyło się w Londynie, w dniach 17 i 18 maja 2007 roku. Podobnie jak pozostałe zakończyło się wydaniem przez ministrów komunikatu, podsumowującego dotychczasowe osiągnięcia Procesu i ustalającego kolejne priorytety. Dokument wskazuje także fakt, że program kształcenia przez całe życie nie jest wystarczająco rozwinięty i powszechnie dostępny, a tym samym wymaga ciągłego ulepszania. W chwili obecnej w Procesie Bolońskim uczestniczy 50 państw, w tym 27 krajów członkowskich Unii Europejskiej.

Jednocześnie warto wspomnieć o opublikowanym przez Komisję Europejską 5 marca 2003 roku komunikacie zatytułowanym „Rola Uniwersytetów w Europie Wiedzy", który porusza kwestie przyszłości Europejskiego 
społeczeństwa wiedzy. Zdaniem Komisji, rozwój gospodarki opartej na wiedzy uzależniony jest od takich czynników jak: tworzenie nowej wiedzy (new knowledge), wdrożenie jej w proces edukacyjny, rozpowszechnianie oraz wykorzystanie jej w usługach i przemyśle. Dlatego też Komisja definiuje nowe wyzwania dla europejskich instytucji szkolnictwa wyższego, jakimi są wzrastający popyt na studia wyższe (ich umasowienie), proces umiędzynarodowiania edukacji i badań naukowych, rozwój bliskiej i efektywnej współpracy między instytucjami edukacyjnymi i przemysłem, wzrastająca liczba miejsc, gdzie podejmowane są działania naukowe, reorganizacja wiedzy i stawienie czoła nowym oczekiwaniom ${ }^{4}$. Ten komunikat to przede wszystkim odpowiedź na wyzwanie, jakim jest dosyć niska konkurencyjność uniwersytetów europejskich na arenie światowej, co wynika przede wszystkim z mniejszych środków przeznaczanych na ich finansowanie.

\section{Problemy i przeszkody związane z funkcjonowaniem Procesu Bolońskiego na przykładzie programu Socrates/Erasmus}

Program Erasmus został ustanowiony w 1987 roku jako europejski program wyjazdów stypendialnych dla studentów, a w latach 90-tych objął także inne formy współpracy między uczelniami. W 1995 roku został włączony do wspólnotowego programu współpracy europejskiej w dziedzinie edukacji - Socrates. Celem Erasmusa jest podnoszenie jakości kształcenia w krajach w nim uczestniczących, poprzez rozwijanie międzynarodowej współpracy między uczelniami, jak również wspieranie mobilności studentów i pracowników szkół wyższych. W roku akademickim 2007/2008 Erasmus stał się częścią programu „uczenia się przez całe życie” (w ramach strategii przewidzianej na lata 2007-2013). Mogą w nim uczestniczyć szkoły wyższe, które otrzymały od Komisji Europejskiej Kartę Uczelni Erasmusa, czyli certyfikat, dzięki któremu uczelnia może się ubiegać o rozmaite fundusze na działalność związaną z jego realizacją.

Z każdym rokiem liczba szkół uczestniczących w programie rośnie, co umożliwia studentom wybór z coraz szerszej oferty wymiany studenckiej. Przed wyjazdem muszą oni jednak zmierzyć się z wyzwaniem, jakim jest skompletowanie potrzebnych dokumentów. Najważniejszy z nich to porozumienie o studiach (tzw. learning agreement), w którym zostaje zapisany program dydaktyczny realizowany przez studenta na uczelni przyjmującej, będący podstawą rozliczenia po powrocie (co umożliwiać ma ECTS). W przytłaczającej większości przypadków okazuje się jednak, że programy realizo-

K. Pawłowski, Rediscovering higher education in Europe, Bukareszt 2004, s. 20-21. 
wane na uczelniach partnerskich różnią się w zasadniczy sposób i zwłaszcza w dziedzinie nauk społecznych, trudno studentowi znaleźć dokładnie takie przedmioty, które w danym roku powinien zrealizować na swojej uczelni macierzystej. Zgodnie z założeniami Procesu Bolońskiego taki problem nie powinien mieć miejsca, gdyż w „Europie wiedzy” nie chodzi przecież o unifikację programów nauczania, ale ich harmonizację. W chwili obecnej, po powrocie ze stypendium, student często staje przed koniecznością uporania się „z zaległościami”, a zdarzają się też przypadki powtarzania roku. Dlaczego tak się dzieje? W wypadku Polski „winna” jest zarówno mała „elastyczność” uniwersytetów, jak i obowiązek realizacji tzw. podstawy programowej, czyli zestawu przedmiotów, które każdy absolwent danego kierunku zaliczyć musi. Tym samym, jeśli nie znajdzie „odpowiednika” danego przedmiotu za granicą, zobowiązany jest zrealizować go prędzej czy później po powrocie do kraju. Tym samym staje się „ofiarą” wciąż niepełnej harmonizacji programów nauczania, mylnie utożsamianej z ich unifikacją, czyli przeświadczeniem, że „każdy musi umieć to samo”. A przecież absolwent danego kierunku, który nie zaliczyłby na przykład trzech przedmiotów realizowanych przez wszystkich na jego uniwersytecie, a za to cztery inne, których u siebie nie ma na rodzimej uczelni, to przyszłemu pracodawcy (który ma możliwość zauważenia takiego faktu dzięki suplementowi do dyplomu), wydałby się przecież nawet bardziej atrakcyjny niż inni. Problemy te jasno wskazują jak istotna i pilna jest pełna realizacja założeń Procesu Bolońskiego, aby studentom wyjazdy na stypendia nie kojarzyły się z ryzykiem i zaległościami, ale przede wszystkim z szansami.

Mimo pewnych trudności nie można wszakże nie dostrzegać jak wiele korzyści niesie ze sobą odbycie części studiów poza granicami kraju. Jest to przede wszystkim możliwość innego podejścia do problemów i zagadnień naukowych, poznanie nowych metod i technik nauczania, jak również dostęp do niedostępnych w kraju źródeł oraz publikacji naukowych. Pobyt na uczelni partnerskiej to także, poza wymianą kulturową, obieg doświadczeń czy wreszcie szansa realizacji pierwszych projektów naukowych. Co więcej, zdarzają się przypadki, w których po pobycie na stypendium, student zostaje przyjęty na uczelnię partnerską i tam kończy studia. Zresztą, wprowadzenie trójstopniowych studiów ma pozwolić studentom kontynuowanie np. studiów magisterskich na dowolnej uczelni partycypującej w programie i to niekoniecznie na identycznym kierunku, na jakim rozpoczęli studia. Otwiera im to szereg możliwości związanych zarówno z rozwojem osobistym i zdobyciem zgodnego $\mathrm{z}$ ich zainteresowaniami, wszechstronnego wykształcenia, jak też z przyszłą karierą zawodową czy naukową. 


\section{Podsumowanie}

Konstrukcja Europejskiego Obszaru Szkolnictwa Wyższego to projekt mający złożoną genezę. Z jednej strony, sporo inicjatyw wykazały środowiska uniwersyteckie, dążące do rozwoju „kultury europejskiej”. Z drugiej strony, także rządy krajów wykazały chęć stworzenia szkolnictwa wyższego opartego na zasadzie jakości, będącego jednocześnie elementem tożsamości kulturowej Europy.

Rok 2010, jako ostateczny moment realizacji reformy, zdaje się być realny, choć kwestia zwiększonej mobilności i automatycznego uznawania dyplomów europejskich, może wymagać dłuższego okresu. Proces Boloński nadal znajduje się na etapie wdrażania i niesie ze sobą wiele pytań dotyczących jakości nauczania i metod ewaluacji. Co jednak najistotniejsze, Europa wydaje się rozumieć, że także od rozwoju edukacji zależy jej przyszłość i pozycja międzynarodowa, dlatego tak ważne jest rozwijanie współpracy w tej dziedzinie. Nie chodzi jednak tylko o wydawanie wspólnych deklaracji, ale przede wszystkim o konkretne działania, które pozwolą urzeczywistnić wszystkie cele „Europy wiedzy”. Jednocześnie warto już w tym momencie postawić pytanie o to, jakie faktyczne możliwości zatrudnienia będą stały przed absolwentem posiadającym dyplom europejski. Czy rzeczywiście łatwiej znajdzie on pracę w innym kraju członkowskim? I jaka będzie „wartość" dyplomów europejskich w porównaniu $\mathrm{z}$ dyplomami japońskich czy amerykańskich uczelni?

J O A N N A J Ó Ź W I C K A, M O N K A K U L W I C K A 


\section{Genesis and development of the European Higher Education Area (EHEA)}

The aim of this article is to present the idea of European Higher Education Area, its origins and the most important documents, as well as turning points in the development of this ambitious project. European Higher Education Area (EHEA) is being introduced as an objective of the Bologna Process. Its main purpose is a creation of more comparable, compatible and coherent system of higher education in Europe. Bologna process is named after the place it was proposed - the University of Bologna, where Ministers of Education from 29 countries signed famous Bologna Declaration. The document is their pledge to reform the structures of higher education systems in a convergent way. In spite of the fact that Bologna process aims at creating convergence, it is not a path towards the "standarisation" or "uniformisation" of European higher education. The fundamental principles of autonomy and diversity are respected. European space for higher education is being created to enhance the mobility of students (as well as trainees and graduates) and teachers (as well as researchers) and to increase the international competitiveness of European higher education. The whole project should be completed in 2010. The most important of its objectives are the adoption of a common framework of readable and comparable degrees (including the implementation of the Diploma Supplement), the introduction of undergraduate and postgraduate levels in all countries and compatible credit systems (European Credit Transfer System - ECTS). Finally, the Bologna Declaration emphasises the necessity of remaining obstacles (both administrative and financial) elimination to free mobility of students.

The article focuses also on the further governmental meetings (and its final Communiqués), which followed up the Declaration. They were held in Prague (2001), Berlin (2003), Bergen (2005) and London (2007). Despite the fact that a lot of improvements have been made, there are still some obstacles impeding the full mobility. They are presented from a student's point of view. An example of the Socrates/Erasmus program is analysed. The program is an educational initiative of the European Commission. It promotes cooperation and mobility in higher education and it was replaced by the Lifelong Learning Program 2007-2013. 